\title{
THE FUZZY-BASED SMART CHARGING MANAGEMENT SYSTEM FOR AN ELECTRIC VEHICLE PARKING LOT INCLUDING A ROOF-TOP PV SYSTEM
}

\author{
*Sitkı GÜNER, Department of Electrical-Electronic Engineering D, Istanbul Arel University, Turkey, sguner@arel.edu.tr \\ (iD) https://orcid.org/0000-0003-1085-0474) \\ Salih Serkan KIR, Department of Electrical-Electronic Engineering D, Istanbul Arel University, Turkey, sskir@enerji.istanbul \\ (iD) https://orcid.org/0000-0002-3282-2530) \\ Received: 05.02.2020, Accepted: 30.05.2020 \\ *Corresponding author \\ Research Article \\ DOI: $10.22531 /$ muglajsci.684822
}

\begin{abstract}
Electric vehicles (EVS) and photovoltaic (PV) systems are one of the most appropriate coupled facilities with each other in smart grids. The goal of this study is to develop a fuzzy-based smart charging management system (SCMS) in order to enable more economic benefits to the EV parking lot from the roof-top PV system under market conditions with dynamic pricing. To achieve this, PV model, parking lot model and energy market model are generated and they are considered as the inputs of the SCMS. The SCMS decides whether the energy generated by the PV system is injected into the grid or used for charging electric vehicles. All models are generated using real system data in this study. Furthermore, using bi-facial PV panels in the PV system simulation is one of the novel approaches of this study. Charging EVs in the PLs from renewable energy resources is very important as it will facilitate the management of this mobile load in the near future. The results of this study will both help to manage the EV load and increase the profit of the EV PL.

Keywords: Bi-facial photovoltaic panel, Electric vehicle parking lot, Fuzzy logic, Photovoltaic system, Smart charging management system,

\section{FOTOVOLTAİK ÜRETIM SISSTEMINE SAHİP ELEKTRÍKLİ ARAÇ OTOPARKI İÇİN AKILLI ŞARJ YÖNETIM SISTEMI}

\section{Özet}

Bu çalışmanın amacı, dinamik fiyatlamanın olduğu piyasa koşullarında otoparkın çatısına kurulan fotovoltaik üretim sisteminin ürettiği enerjiden daha fazla ekonomik fayda sağlamak için bulanık mantık tabanlı akıllı şarj yönetim sistemi geliștirmektir. Bunu yapabilmek için fotovoltaik üretim sisteminin, otopark ve enerji piyasası modelleri oluşturulmakta ve modeller aklll şarj yönetim sistemine giriş olarak verilmektedir. Akıllı şarj yönetim sistemi fotovoltaik üretim sisteminin ürettiği enerjinin şebekeye satılacağına veya elektrikli araçların şarj edileceğine karar vermektedir. Bu çalışmadaki modellerde gerçek veriler kullanılmaktadır. Ayrıca, fotovoltaik üretim sistemi simülasyonunda çift yönlü fotovoltaik panellerin kullanması bu çalışmanın yeni yaklaşımlarından biridir. Yakın gelecekte elektrikli araçların otoparklarda yenilenebilir enerji kaynaklarından şarj edilmesi bu mobil yükün yönetimini kolaylaştıracağı için çok önemlidir. Bu çalışmanın sonuçları hem elektrikli araç yükünün yönetimine yardımcı olacak, hem de otoparkların kazancını artıracaktır.

Anahtar Kelimeler: Akıllı şarj yönetim sistemi, Bulanık mantık, Çift yönlü fotovoltaik panel, Elektrikli araç, Fotovoltaik üretim sistemi, Otopark.

Cite

Güner, S., Kır, S. S., (2020). "The fuzzy-based smart charging management system for the electric vehicle parking lot included a roof-top pv system", Mugla Journal of Science and Technology, 6(0), 18-24.

\section{Introduction}

With the increasing awareness of reducing carbon emissions, the participation of electric vehicles (EVs) and renewable energy sources (RESs) in power systems is increasing day by day. One of the easiest and most cost-effective ways of integrating these two systems with power system is installing a roof-top PV system in an EV parking lot (PL). Because of the high price of terrains in metropolitan cities like Istanbul, EV PLs facilitate the integration of these two facilities, PV systems and EVs, with the power grid. In addition, solar carport in the PLs can charge the EVs during the daytime and at the same time provide energy from PV systems to the power grid [1].

This study focuses on the "Park-Ride $(\mathrm{P}+\mathrm{R})$ " type PLs for combining PV system and EV charging infrastructure. The results of the study proposed in [2] show that the payback period of a roof-top PV system installed in an EV PL is 7 years. On the other hand, additional storage units will improve system reliability to compensate for 
the charging load of EVs with the generation of the rooftop PV system in the EV PLs. However, it should be taken into consideration that this situation will bring additional cost [3].

To charge EVs with roof-top PV system is not a new method or idea, and even there are many studies on this subject. [4-6]. The analysis of the energy-economy relationship of an EV charging station and the reduction of carbon emissions by simulating PV system in a workplace PL was presented in [7].Fuzzy-based decision-making algorithms have also been frequently used in energy management studies. In [8], the energy management strategy for the house having a PV system was presented with a fuzzy-based algorithm. In addition, fuzzy-based algorithms were used in subjects such as energy cost, consumption and peak load reduction of smart houses [9]. There were also studies using fuzzy logic models for EV charging management [10-12].

The main goal of this study is to develop a fuzzy-based smart charging management system to enable more economic benefit to the EV PL from the roof-top PV system. For this purpose, a PV system model and a charging load model of EV PL are developed. In this study, the models are generated by using car arrival/departure patterns and location information of an existing PL in Istanbul. Furthermore, bi-facial solar panels are used in the simulation of the PV system. Bifacial solar cells, unlike normal PV cells, also provide additional absorption from the back, more solar absorption and more electricity is produced [13]. In this way, it is aimed that a more efficient technology, which will increase its use in the following years, will contribute to the originality of the study.

Firstly, the daily charging load curve of the EV PL is determined by using the real data of car arriving/departing times of a "P+R" type PL which has 500 car capacity in Istanbul. To do this, Monte-Carlo simulation is used. In addition, the generation capacity of the rooftop PV system is obtained using an appropriate simulation software. The location information of the PL is also used in order to obtain a more realistic PV system design. In the second stage, a fuzzy-based algorithm is developed to decide how the energy generated by the PV system through the day is used (selling to the power grid or charging EVs in the PL). With the hourly results of these models, the PL operator will be able to manage this energy (generated by the PV system) more efficiently according to the electricity price variation during the day times.

The remainder of the study is organized as follows: Simulation model generated in this study is described in Section 2, the details of the SMCS is given in Section 3, and conclusions are presented in Section 4.

\section{Simulation Models}

In this study, three models, the charging load model of the PL, the PV system model and the energy market model, are generated for SCMS of the EV PL. The SCMS works using these models and the relation between SCMS and these models are shown in Figure 1. These models are generated using real data. In addition, a single line scheme of the SCMS is given in Figure 2. As shown in Figure 2, the energy generated by the PV system, EV charging load and electricity price information is inserted into the SCMS. According to this information, the SCMS decides with the fuzzy-based algorithm whether this energy is sold to the power grid or used for charging the EVs.

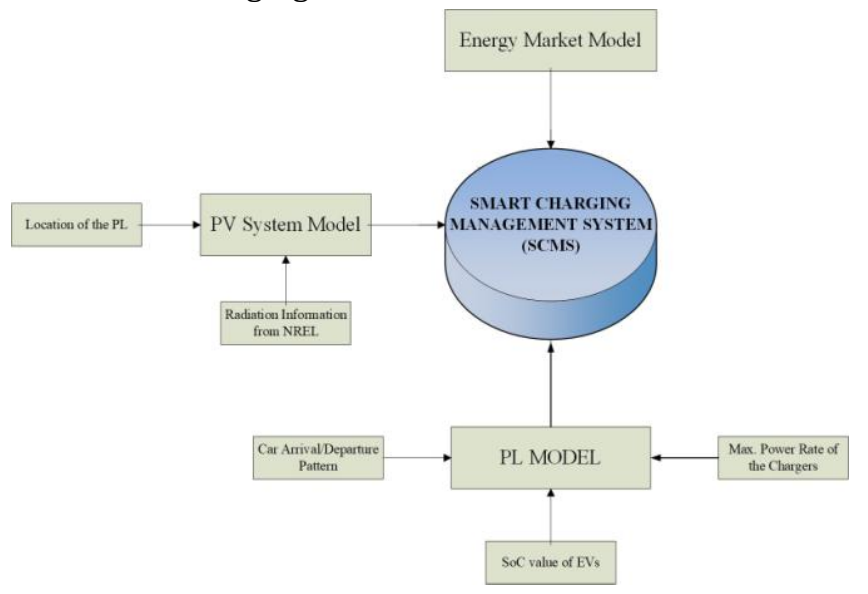

Figure 1. The scheme of the SCMS

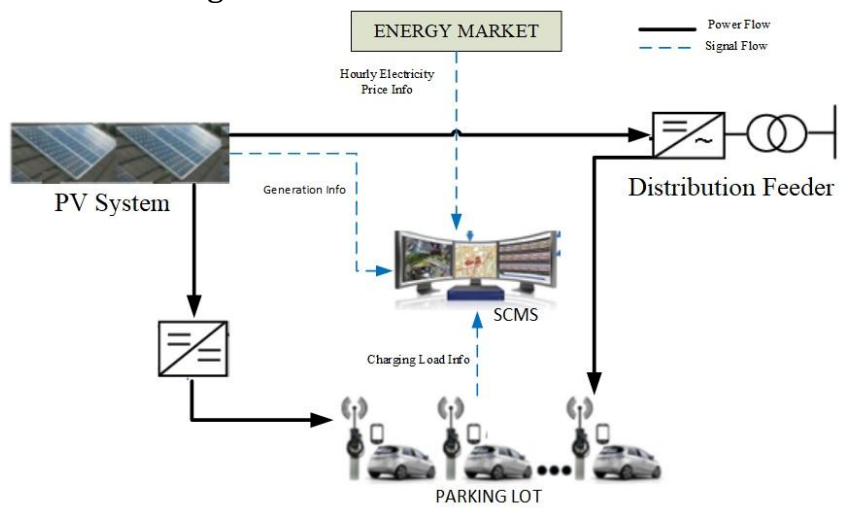

Figure 2. Single-line diagram of the SMCS

\subsection{The Parking Lot Model}

The charging load of the EV PL is obtained by the PL model which is dependent on deterministic and probabilistic variables such as car arrival/departure pattern, battery state of charge (SoC) when an EV arrives in the PL, battery capacity of EVs, maximum power rate of chargers.

In order to determine the arrival/departure pattern of the EV PL, 4 years data of a PL which has 500 car capacity in Istanbul is used. The raw data includes only arriving dates, arriving times, departing dates, and departing times for each car. This data is clustered 15 minutes time bins in the specified period. The number of arriving and departing cars for each time bin is calculated as given in Figure 3, which indicates car arrival times of the PL for a sample day. After several operations of raw data processing, arrival times of the vehicles arriving at the PL were determined by using the 
two-parameter cumulative Weibull distribution which is expressed in Equation 1. In this equation, $\alpha$ is the scale parameter, $\beta$ is the shape parameter, and $x$ is an integer indicating that the arrival time of the vehicle is within the 15 minutes period starting at 07.00. The relationship between car arriving time in minutes and $x$ variable is given in Equation 2. The unit of variable $t$ in this equation is minutes. Details of the processes for determining stochastic car arriving times are given in $[14,15]$. Weibull parameter values in accordance with vehicle arrival data of the PL were calculated as $\alpha=0.9831, \beta=16.8$ using MATLAB.

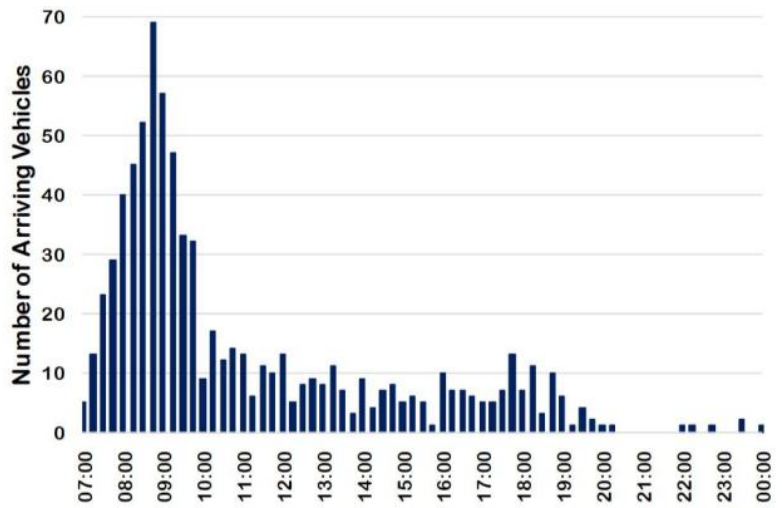

Figure 3. Car arrival times in the PL during a weekday

$$
\begin{gathered}
F(x)=1-e^{-\left(\frac{x}{\beta}\right)^{\alpha}}, \quad 0 \leq x \leq 68 \\
x=\operatorname{ROUNDUP}\left[\frac{t-420}{15}\right] ; 420 \leq t[\mathrm{~min}] \leq 1440
\end{gathered}
$$

The parking duration of the cars is one of the parameters that affect the charging load of the EV PL. The variation of the parking duration of the PL in accordance with car arriving times is shown in Figure 4. The parking duration of the cars arriving at the PL until 09.00 a.m can be modelled using a normal distribution function. However, there is no appropriate distribution function for the time slot after 9.00 a.m. Therefore, the parking duration of the cars in the PL is determined by kernel density estimation. The details of selecting this function are described in [16]. The kernel density estimation formula is given in Equation 3. In the kernel density function, $N$ represents the sample size (number of data), $K(\cdot)$ shows the kernel smoothing function, $h$ gives the bandwidth and $x_{i}$ represents the sample data point. In this study, Gaussian kernel is used as smoothing function and bandwidth is selected as 1 .

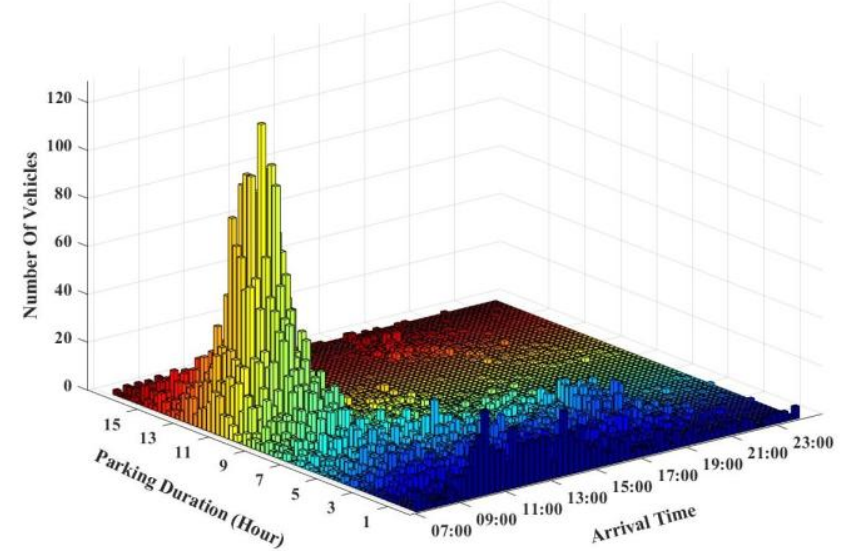

Figure 4. Parking duration versus arrival time of the cars

$$
f(y)=\frac{1}{N h} \sum_{i=1}^{N} K\left(\frac{y-y_{i}}{h}\right)
$$

Battery capacity of EVs varies according to brands and segments. However, there are no statistical data on the frequency of use of battery capacities. Therefore, the battery capacity of EVs is considered to be $25 \mathrm{kWh}$ in this study. In addition, a study conducted in [17] found that average millage of cars is $50 \mathrm{~km}$ per day in Istanbul. Using this data, the SoC value when an EV arrives at the $\mathrm{PL}$ is added to the modelling with normal distribution $(\mu$ $=70 \%, \theta=15 \%$ ).

The maximum power of EV chargers varies depending on where they are used. The power rate of chargers used in areas such as shopping centers, business centers or car parks varies between $4 \mathrm{~kW}$ and $19.2 \mathrm{~kW}$ [18]. In this study, the maximum power of the chargers is assumed as $12.5 \mathrm{~kW}$. In addition, it is assumed that half of the capacity of the PL is equipped with chargers.

In this study, EV batteries are assumed to have lithiumion properties. The charging load of the PL is calculated by the Equations 4 and 5 using the lithium-ion battery characteristic given in $[19,20]$.

$$
\begin{gathered}
P_{i}(t)= \begin{cases}P_{\max } & \text { if } \operatorname{SoC}_{i}(t)<\% 90 \\
0.2 * P_{\max } & \text { if } \% 90 \leq \operatorname{SoC}_{i}(t)<\% 95 \\
0.08 * P_{\max } & \text { if } \% 95 \leq \operatorname{SoC}_{i}(t)<\% 98\end{cases} \\
P_{P L}(t)=\sum_{i=1}^{N(t)} P_{i}(t)
\end{gathered}
$$

$P_{\max }$ is the maximum power of the charger $(12.5 \mathrm{~kW})$, $N(t)$ is the number of EV in the PL at time $t, P_{1}(t)$ is the power absorbed by $i^{\text {th }} \mathrm{EV}$ at time $t, P_{P L}(t)$ is the total charging power of the PL at the moment $t$.

Eventually, other probabilistic and deterministic parameters which are needed to obtain the charging load of the PL are computed. Probabilistic parameters are determined using the raw data of the PL and deterministic parameters are assumed because of the lack of the the proper statistical data. 
- The number of all vehicles that remain throughout the night: $N_{0}$; Normal $(\mu=26$ cars, $\sigma=4$ cars).

- Daily total number of vehicles arriving at the PL in the specified time interval $7: 00$ 23:59) : Total $_{\text {car; }}$ Normal $(\mu=710, \sigma=20)$

- Maximum vehicle capacity $=500$ cars; 250 which are equipped with $\mathrm{EV}$ chargers.

- The type of arriving/departing vehicles in the specified time interval: type $\mathrm{EV}_{\mathrm{EV}}$ : Binary (1=EV, $0=$ ICE)

- $\quad$ Maximum charging power $=12.5 \mathrm{~kW}$ [18]

The charging load of the PL is calculated with 1000 iterations by sequential Monte-Carlo (MC) simulations. As a result of these calculations, the maximum charging load for the critical hours is obtained as given in Figure 5. The details for obtaining the PL load curve for the critical charging interval can be found in [14-16, 21].

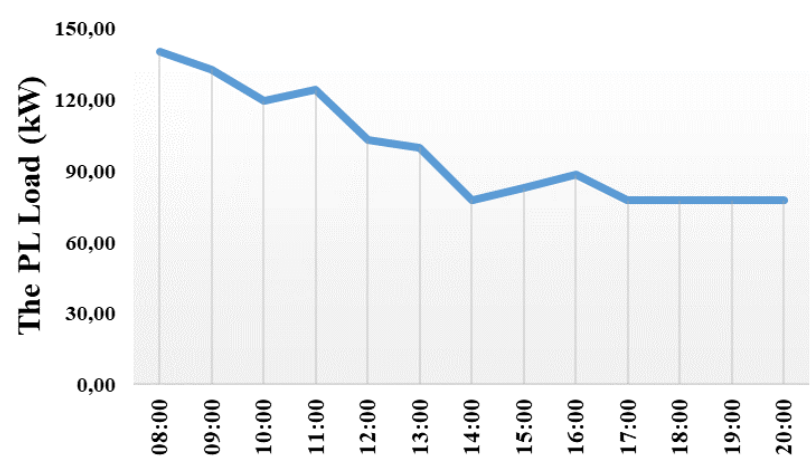

Figure 5: PL load curve

\subsection{PV System Model}

One of the main purposes of EVs is to charge them using RESs for reducing carbon emission. Inspired by this idea, a roof-top PV system which of capacity is 428.4 $\mathrm{kWp}$ is designed by appropriate simulation software to cover the roof of the PL where car arrival/departure data was provided by ISPARK. The PV system is constructed on the marked area in Figure 6 which illustrates the satellite view of this PL by using Google Maps. Furthermore, this PV system is performed with bifacial monocrystalline PV panels. It is one of the novel approaches of this study.

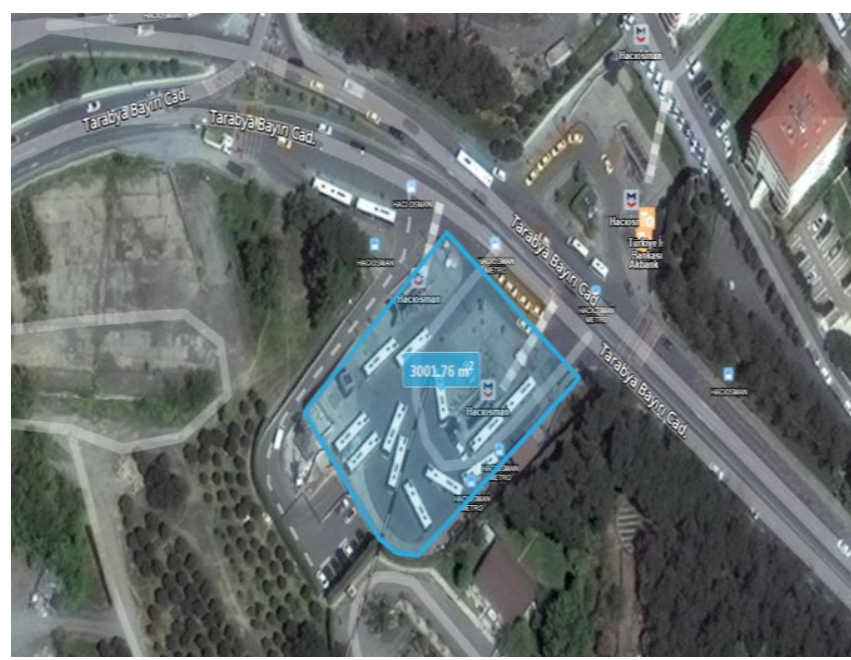

Figure 6: The location of the PL by using Google Maps

In the PV system, swan bi-facial monocrystalline type solar modules of Jinko Solar are adopted with a $300 \mathrm{Wp}$ nominal power [22]. The total number of PV modules is 1428 pieces and the PV system is connected with both power grid and EV chargers. The PV arrays are tilted at $7^{\circ}$ and their orientation angle is obtained as 140 -degree southeast direction considering the physical layout of the PL. As a result of the simulation, the total annual energy generated by PV system is found $603.739 \mathrm{kWh}$. In the simulation, bi-facial monocrystalline panels of Jinko Solar were used [22]. Current-voltage (I/V) and power-voltage curve of bi-facial monocrystalline panel is given in Figure 7. Furthermore, 7 pieces ABB 3-phase central solar inverter of $55 \mathrm{~kW}$ are used in this system [23]. The placement of the PV system is shown in Figure 8.

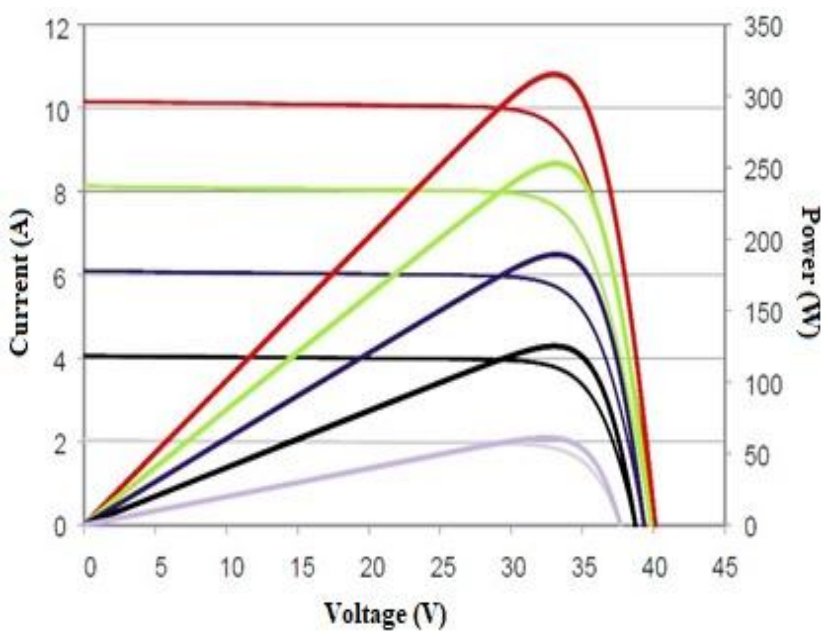

Figure 7: Current-voltage (I/V) and power-voltage curve of the PV module [22] 


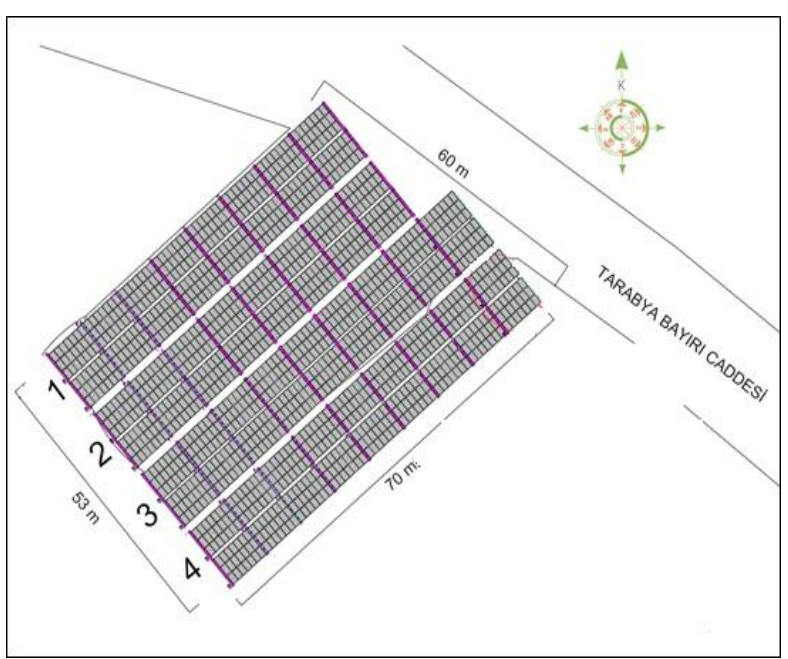

Figure 8: The placement of the PV system

As a result of the simulation, the total generation forecast of the PV system for each month is obtained as given in Figure 9 and its average daily generation for April is shown in Figure 10.

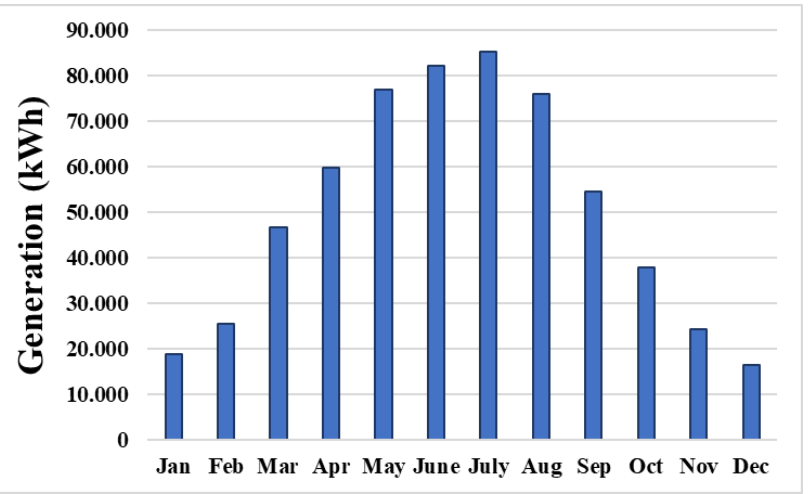

Figure 9: Total generation forecast of the PV system for each month

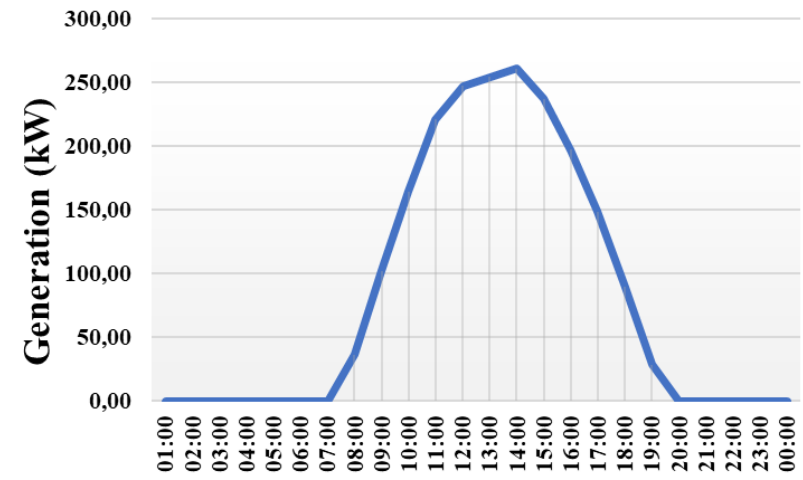

Figure 10: Average daily generation curve of the PV system for April.

Managing hourly generated energy of the PV system is decided by the SCMS. The simulation software is used to obtain hourly generated energy of PV system per year. Since the average number of cars arriving at or departing from this PL from November to April is very close, the generation of the PV system on April is considered in this study [24]. It will be explained briefly in Chapter 3.

\subsection{Energy Market Model}

The energy market in Turkey has not yet had a fully deregulated environment. Since this study is performed considering the future power system environment, it is assumed that there is dynamic pricing in power systems. Thus, electricity price is determined according to the supply-demand balance. One-year data about electricity price of a large electricity company in the United States (US) covering the period between April 2017 and March 2018 was used for simulating the variation of dynamic energy price in the energy market model [25].

According to this data, electricity price variation for a sample day is given in Figure 11. Moreover, electricity price variation at $09.00 \mathrm{a} . \mathrm{m}$. in the year-round weekdays is given in Figure 12. The $\mathrm{x}$-axis of Figure 12 indicates the number of weekdays throughout the year. These figures show that both the daily and annual electricity price is not regular. Therefore, it is obtained the histogram of the electricity price of each hour for generating random hourly electricity price. To do this, kernel density function is used. Since the proportional change of daily electricity price is more important for this study, the value of the electricity price in terms of US dollars is not taken into consideration.

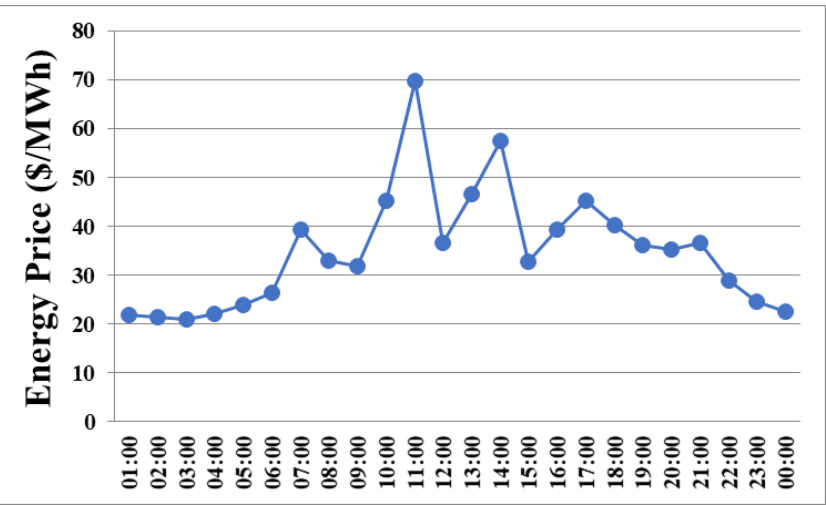

Figure 11. Electricity price variation for a sample day

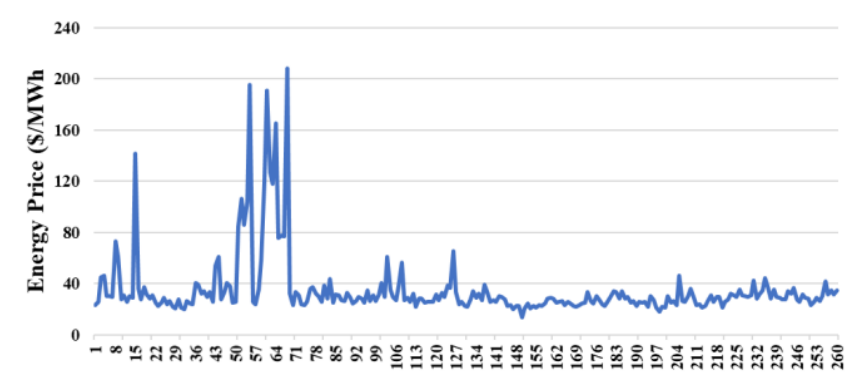

Figure 12 . Electricity price variation at 09.00 a.m. in year-round weekdays.

\section{The Fuzzy-Based SCMS}

The SCMS provides the PL operators with a fuzzy-based algorithm how to manage the energy generated by the PV system during day times. The fuzzy-based decision 
making algorithm is briefly explained in this chapter. This decision-making algorithm is developed using fuzzy logic toolbox in MATLAB. Three membership functions (Low, Normal, High) for the PV system model and the PL model and two membership functions (Low, High) for the energy market model are defined as the inputs of the fuzzy logic model. Furthermore, 2 membership functions (Charge, Grid) are defined for its output. These membership functions are given in Figure 13.

As explained Chapter 2.1, 1000 different car arrival/departure patterns are generated using MonteCarlo simulation. Then, charging power for every specified hours is calculated in each iteration. This information is combined with PV generation and randomly generated electricity price for each hour. The SCMS uses these inputs on every hour in each iteration for deciding energy flow to the grid or to EVs. The aim of this study is to increase the financial profit of the PL from selling energy. In order to determine the contribution of the SCMS, a base case is obligatory. Charging EVs has major priority in the base case. If an EV need to charge, it is charged from the grid or PV system in any case regardless of electricity price and excess energy generated by the PV system is sold to the grid. The daily financial profit of the PL from energy trading which is selling energy generated by the PV system and buying energy from the grid is calculated.

Second case is calculation of daily financial profit of the PL with the energy-flow decision provided by the SMCS. According to the working principle of the SCMS as a mentioned above, this calculation process is repeated. As the results of the two cases compared, the SCMS can provide $12 \%$ more gain to the PL. It is noted that the energy spent from the PV system for charging EVs is not involved in the PL's profit for both cases.

\section{Conclusion}

Making use of the roof of the EV PL with a PV system creates an opportunity for both a RES to join the power grid, and also to charge EVs from a source that does not harm the environment. A fuzzy-based SCMS was proposed for managing energy generated from a rooftop PV system of the EV PL in this study. The proposed SMCS provides more financial profit $12 \%$ compared to uncontrolled charging management. This is an initial study for generating advanced SCMS. The results of this study will be used to improve the smart charging management system that uses Multi-Criteria Decision Making (MCDC) algorithm in the future.

In recent years, the number of studies on EV PLs has increased significantly. Its most important reason is the need for two-way power flow to be achieved when switching to the smart grid structure with the increasing number of distributed generations. It is expected that the development and implementation of EV charging systems with RESs will continue to attract the attention of future researches.

Charging EVs in the PLs from renewable energy resources is very important as it will facilitate the management of this mobile load in the near future. Commercial and private PLs can be used for this purpose. In addition, PV system is used on the roof of the PLs, creating the opportunity for RESs to join the network and charging the EVs from the green energy source. The increased use of EVs will make positive contributions towards reducing emissions and increasing renewable energy sources. The results of this study will both help to manage the EV load and increase the profit of the EV PL.
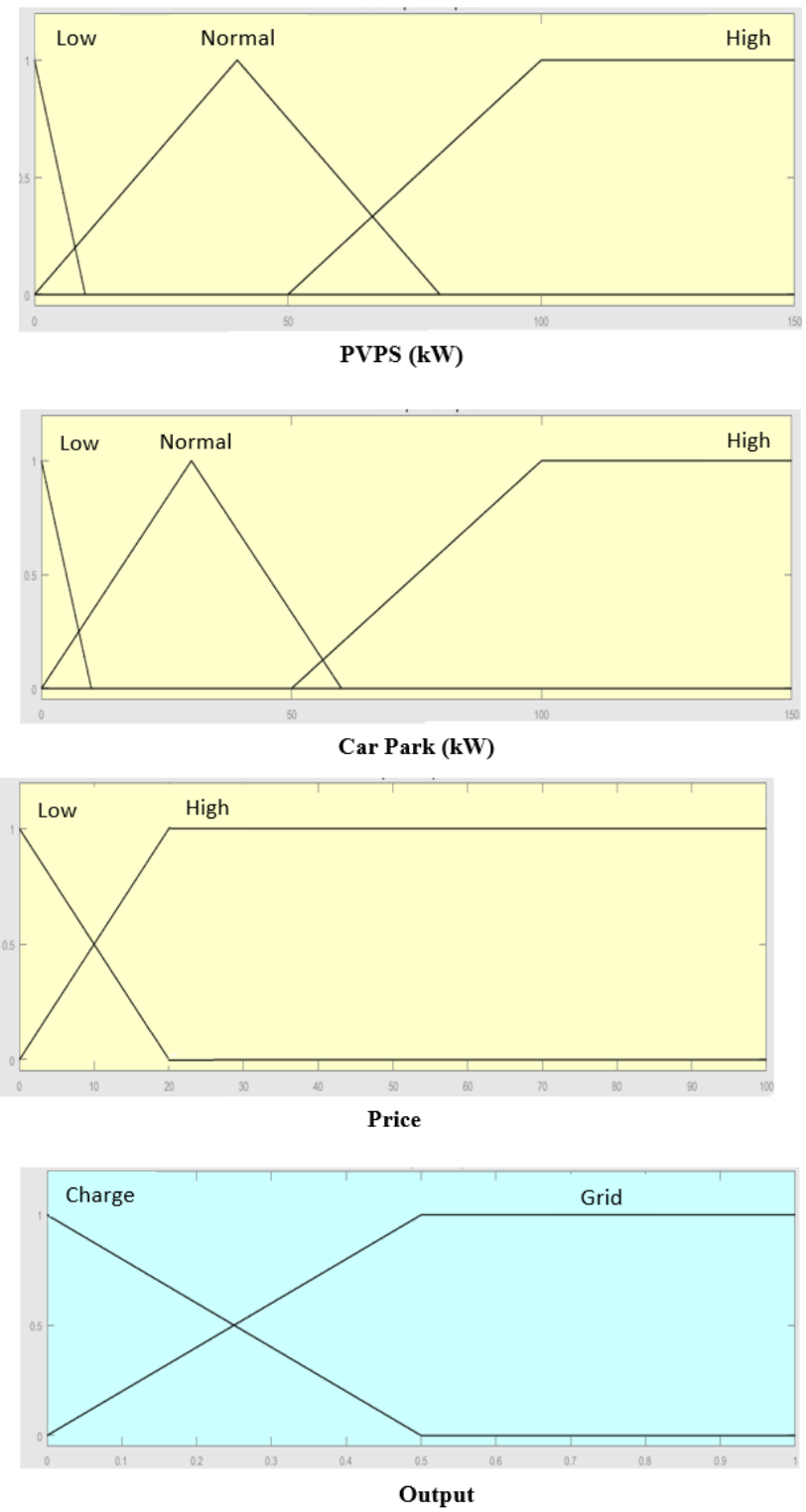

Figure 13: Input/output membership functions of the fuzzy logic model.

\section{Acknowledgment}

We would like to thank ISPARK General Directorate for their contribution to the study.

This work was mainly supported by The Scientific and Technological Research Council of Turkey (TUBITAK) under project Grant No.119E646. 


\section{References}

[1] Birnie,D. P., "Solar-to-vehicle (S2V) systems for powering commuters of the future," Journal of Power Sources, Vol: $186,539-542,2009$.

[2] Figueiredo, R., Nunes, P., and Brito, M. C., "The feasibility of solar parking lots for electric vehicles," Energy, Vol: 140, 1182-1197, 2017.

[3] Brenna, M., Dolara, A., Foiadelli, F., Leva, S. and Longo, M., "Urban scale photovoltaic charging stations for electric vehicles," IEEE Trans. On Sustainable Energy, Vol: 5, Issue: 4, 1234 - 1241, 2014.

[4] Solar Power World, "Photoblog: Assurant celebrates earth day with new solar array", webpage: https://www.solarpowerworldonline.com/2013/04/pho toblog-assurant-celebrates-earth-day-with-new-solararray.

[5] Maryland Energy Administration, "Parking lot solar PV canopy with EV charger grant program", webpage: https://energy.maryland.gov/business/Pages/incentives /PVEVprogram.aspx.

[6] Root, L. and Perez, R., "Photovoltaic covered parking lots a survey of deployable space in the Hudson River Valley, New York city, and Long Island, New York", webpage: http://asrc.albany.edu/people/faculty/perez/publication s/Other\%20Papers\%20and\%20Applications/parkings.p df.

[7] Tulpule, P. J., Marano, V., Yurkovich, S., and Rizzoni, G., "Economic and environmental impacts of a PV powered workplace parking garage charging station," Applied Energy, Vol: 108, 323-332, 2013.

[8] Chekired, F. Mahrane, A., Samara, Z., Chikh, M., Guenounou, A. and Meflah, A., "Fuzzy logic energy management for a photovoltaic solar home", $8^{\text {th }}$ International Conference on Sustainability in Energy and Buildings, 2017.

[9] Khalid, R., Javaid, N., Rahim, M. H., Aslam, S., and Sher, A., "Fuzzy energy management controller and scheduler for smart homes," Sustainable Computing: Informatics and Systems, Vol: 21, 103-118, 2019.

[10] Khalatbarisoltani, A., Cepeda, J. C. O., Boulon, L., Lupien, D., Solano, S. J., and Duarte, C., "A new real-time centralized energy management strategy for modular electric vehicles," 2018 IEEE Vehicle Power and Propulsion Conference (VPPC), 2018.

[11] Bandpey, M. F. and Firouzjah, K. G., "Two-stage charging strategy of plug-in electric vehicles based on fuzzy control," Computers and Operations Research, Vol: 96, 236-243, 2018

[12] Jannati, J. and Nazarpour, D., "Multi-objective scheduling of electric vehicles intelligent parking lot in the presence of hydrogen storage system under peak load management," Energy, Vol:163, 338-350, 2018.
[13] Ooshaksarei, P., Zulkifli, R., Alghoul, M., and Zaharim, A., "Terrestrial applications of bifacial photovoltaic solar panels," Proceedings of the 10 $10^{\text {th }}$ WSEAS International Conference on System Science and Simulation in Engineering, 2011.

[14] Guner, S. and Ozdemir, A., "Distributed storage capacity modelling of EV parking lots," International Conference on Electrical and Electronics Engineering, ELECO 2015, 2015 , 359-363.

[15] Guner, S. and Ozdemir, A., "Stochastic energy storage capacity model of EV parking lots," IET Generation, Transmission \& Distribution, Vol: 11, Issue: 7, 1754- 1761, 2017.

[16] Guner, S., Ozdemir, A., and Serbes G., "Impact of car arrival/departure patterns on EV parking lot energy storage capacity," 14th International Conference on Probabilistic Methods Applied to Power Systems PMAPS 2016, 2016.

[17] Yagcitekin, B., Uzunoglu, M., Karakas, A., and Vurgun, M., "Assessment of a car park with electric vehicles," $4^{\text {th }}$ International Conference on Power Engineering, Energy and Electrical Drives 2013, 2013, 961-964.

[18] Yilmaz, M. and Krein, P. T., "Review of benefits and challenges of vehicle-to-grid technology", Energy Conversion Congress and Exposition (ECCE) 2012, 2012.

[19] Marra, F., Yang, G. Y., Træholt, C., Larsen, E., Rasmussen, C. N. and You, S., "Demand profile study of battery electric vehicle under different charging options," IEEE Power and Energy Society General Meeting, 2012.

[20] Zheng, J., Wang, X., Men, K., Zhu, C., and Zhu, S., "Aggregation model-based optimization for electric vehicle charging strategy," IEEE Trans. on Smart Grid, Vol: 4, Issue: 2, 1058-1066, 2013.

[21] Guner, S. and Ozdemir, A., "Impact of EV parking lot on distribution system reliability," 15th International Conference on Probabilistic Methods Applied to Power Systems PMAPS 2018, 2018.

[22] Jinko Solar. https://www.jinkosolar.eu/de/download/datenblaetter. html?file=files/jinko/module/datasheets/en/Eagle $\% 20 \mathrm{P}$ ERC\%20JKM300-320M-60H-BDVP-D1-EN.pdf

[23] ABB. https://library.e.abb.com/public/bbea91b65f5e41199b7 8c39c987c9aea/PVI-55.0-330.0_BCD.00381_EN_RevB.pdf

[24] Guner, S. and Ozdemir, A., "Seasonal impacts on the storage capacity of EV parking lots," 2017 IEEE PES Innovative Smart Grid Technologies Conference Europe (ISGT-Europe), 2017.

[25] PJM, Day-Ahead Energy Market, http://dataminer2.pjm.com/feed/da_hrl_lmps/ definition. 